\title{
EUCARISTIA: FONTE E CUME DA VIDA CRISTÃ
}

\author{
"Tomai e comei, fazei isto em memória de mim" (Lc 22,19)
}

\author{
Dr. Pe. Rogério L. Zanini* \\ Pe. Claudir Meoti ${ }^{\star \star}$
}

DOI: https://doi.org/10.52451/teopraxis.v37i129.9

Recebido: 15 de novembro de 2018 | Aprovado: 01 de março de 2019

Resumo: Para viver uma espiritualidade libertadora, talvez o mais delicado e exigente seja a relação dos católicos com a Eucaristia. Infelizmente, a Eucaristia, o mais precioso tesouro da fé e da vida espiritual, ainda se encontra aprisionada e envolta de estruturas rígidas que nem sempre permitem às pessoas se deliciarem com o mistério. Urge como desafio refazer a centralidade da ceia de Jesus para que ela possa novamente se tornar o alimento comunitário, ligada com a vida e às lutas cotidianas, como sacramento da partilha e do amor de Cristo levado até o extremo (Jo 13,1). A realidade da pandemia com o fechamento das Igrejas/Templos fez perceber os desafios da evangelização em relação à Eucaristia, bem como seus avanços na compreensão da ceia como banquete de solidariedade com os pobres e excluídos. Por isso, a reflexão que segue busca, primeiro, discorrer de forma narrativa sobre os Evangelhos com o objetivo de perceber a centralidade das refeições na vida de Jesus. Em segundo lugar, compreender o sentido do mandamento, deixado por Jesus: fazei isto em memória de mim. E, por fim, em terceiro lugar, o tomai e comei como banquete da vida, rechaçando qualquer perspectiva individualista e farisaica em relação à Eucaristia.

Palavras-chave: Jesus. Eucaristia. Evangelização. Vida.

\section{Introdução}

A pandemia, como não poderia ser diferente, afeta a vida da Igreja. No livro do Apocalipse encontra-se uma passagem, na

* Padre da Diocese de Chapecó. Doutor em teologia pela PUCRS. Professor e Diretor da Itepa Faculdades - Passo Fundo. Email: zaninipastoral@hotmail.com

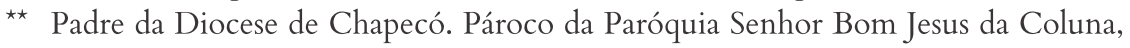
Xanxerê - SC. Formado em filosofia e teologia e pós-graduado em Liturgia e em Iniciação à Vida Cristã - Catequese. Email: claudirmeoti@yahoo.com.br 
qual o autor afirma, referindo-se às comunidades: "quem tem ouvidos, ouça o que o Espírito diz às Igrejas” (Ap 2,7). Se o Espírito é o agente primeiro da evangelização: como nesta realidade obscura, provocada pela pandemia, se revela e atua a força do Espírito nos processos de evangelização? Que diagnóstico eclesial é possível verificar diante do cenário da pandemia? Alguns já se perguntam como será depois da pandemia. Questão importante se estiver embasada numa reflexão correta do cenário deixado por ela. Senão, há o sério perigo de propor respostas a questões inexistentes. Daí a importância de perguntar-se especificamente pela realidade da Eucaristia, fonte e cume da vida cristã, e suas consequências para os processos de evangelização.

Diante das orientações da Organização Mundial da Saúde (OMS) para controlar a contaminação pelo coronavírus, uma das medidas é o distanciamento social. Essa orientação necessária e eficaz transtornou a caminhada de evangelização, principalmente quando foi preciso coibir a participação física dos fiéis na celebração eucarística. Surge o grande questionamento: vamos ficar sem comungar? A pergunta é interessante e sobre o que tentamos discorrer neste texto é o verdadeiro sentido do comungar do Corpo e Sangue de Cristo para a vida daqueles que desejam seguir a proposta do Evangelho.

A reflexão que segue aborda, em primeiro lugar e de forma narrativa, os Evangelhos com o objetivo de perceber a centralidade das refeições na vida de Jesus. Em segundo lugar, em conexão com as narrativas das refeições, busca compreender o sentido do mandamento deixado por Jesus: "fazei isto em memória de mim". E, por fim, em terceiro lugar, o tomai $e$ comei como banquete da vida, rechaçando qualquer perspectiva individualista e farisaica em relação à Eucaristia. Ao refletir esses três pontos, desejamos firmar que a Eucaristia é, sim, central e alimento indispensável aos que seguem a Jesus. Ela é o sustento essencial para a missão de anunciar o Reino de Deus. 


\section{Jesus e as refeições}

Quando se analisa a vida de fé da Igreja católica, fica evidente a importância teórica e prática da Eucaristia. A tradição é longa e muito fecunda historicamente. Desde o início do cristianismo, a Eucaristia se tornou o núcleo por excelência da experiência cristã. Central na vida de Jesus, a Igreja entendeu a Eucaristia, na expressão Concílio Vaticano II (1965), como "fonte e cume da vida cristã". Pela participação no sacrifício eucarístico de Cristo, "fonte e centro [cume] de toda a vida cristã" (LG 10; QA 84), a Igreja se torna o que ela de fato é: comunhão.

Para compreender o processo da configuração da Eucaristia como expressão da realidade comunal da Igreja, é importante voltar às primeiras narrativas dos Evangelhos. Os Evangelhos são a carta magna da grande síntese das palavras-mandamento de Jesus: "fazei isto em memória de mim". Que memória se está atualizando em cada celebração eucarística?

As narrativas bíblicas deixam entrever uma infinidade de momentos em que Jesus se refere ao alimento. São uma gama bem expressiva dos banquetes e refeições realizados na presença de Jesus. Como se dirá a seguir, Jesus revela-se um homem da mesa e colocará quase como necessidade imprescindível a comensalidade para participar do Reino de Deus. As narrativas das refeições, antes de celebrar a última ceia, são uma amostra do reinado de Deus e, também, das dificuldades próprias de os discípulos entenderem a novidade que Jesus traz à humanidade. Quando se percorre as narrativas dos evangelhos, é perceptível que houve uma sequência de outras refeições e banquetes na presença de Jesus, anteriores à última ceia. Sem a preocupação exaustiva de esgotar, retomam-se algumas refeições narradas pelos Evangelhos.

Jesus como peregrino ia de casa em casa compartilhando da 
experiência da vida e acolhendo o que lhe ofereciam. É convidado para fazer refeições e participa com alegria. Jesus também aparece convidando-se para estar na casa das pessoas, como mostra o exemplo de Zaqueu. Encontro que começa no caminho e termina na casa, com a conversão e mudança de vida de Zaqueu (Lc 19,1-10). Há situações inesperadas, em que o banquete é preparado, mas os convidados não aparecem. Jesus contorna aquela decepção, mandando convidar um público marginalizado e excluído, segundo a visão daquela sociedade: os pobres, os aleijados, os cegos e os mancos (Lc 14,15-24). A lição é a possibilidade de autoexclusão em participar do Reino de Deus, não por parte de Jesus, que não exclui ninguém, mas pelo contrário. Ao assegurar que dos pobres é o Reino de Deus, Jesus revela o desejo da universalidade do banquete. No entanto, a participação no Reino não se dá de qualquer forma, é fruto das escolhas, ou melhor, da resposta dada diante das exigências para fazer parte do reinado de Deus.

Algumas refeições se tornam escolas catequéticas para instruir os discípulos na responsabilidade e no compromisso com a fome das pessoas. Exemplo típico é a "multiplicação" dos pães que, apesar das diferenças, é narrada por todos os evangelistas (Mt 14,13-21; Mc 6,30-40; Lc 9,10-17; Jo 6,1-13). $\mathrm{O}$ que importa nesses textos é evidenciar pessoas com fome e o ensinamento de Jesus. Jesus sonda a opinião dos discípulos sobre o que fazer diante do povo faminto e os responsabiliza: "dailhes vós mesmos de comer...”. Os discípulos só veem duas saídas: uma, mandar o povo embora, ou seja, quem tem come e quem não tem se vira como pode. Outra, a saída personalista, com ares messiânicos, ou seja, alguém vai comprar pão para todos. E surge o caminho aberto por Jesus: avaliar o que possuem, organizar, partilhar, cuidar das sobras e evitar os desperdícios. É a lição de outro modo de pensar como deve ser a nova sociedade testemunhada pelos discípulos/cristãos, seguidores de Jesus em todos os tempos. 
O Papa Francisco traz presente esse texto, justamente ao se referir e desejar uma Igreja em saída. "Saiamos, saiamos para oferecer a todos a vida de Jesus Cristo"! Acrescenta: "Prefiro uma Igreja acidentada, ferida e enlameada, por ter saído pelas estradas, a uma Igreja enferma pelo fechamento e a comodidade de se agarrar às próprias seguranças”. E revela seu maior medo:

Mais do que o temor de falhar, espero que nos mova o medo de nos encerrarmos nas estruturas que nos dão uma falsa proteção, nas normas que nos transformam em juízes implacáveis, nos hábitos em que nos sentimos tranquilos, enquanto lá fora há uma multidão faminta e Jesus repete-nos sem cessar: 'Dai-lhes vós mesmos de comer' (Mc 6,37) (EG 49).

O evangelista São João, ao narrar a multiplicação dos pães, apresenta uma realidade bem curiosa. Para o que interessa aqui, João da mesma forma fala da multiplicação dos pães, no entanto, logo em seguida, Jesus percebe que o povo e os discípulos o estão seguindo e, surpreendentemente, os adverte: "Em verdade, em verdade, vos digo: vós me procurais, não porque vistes sinais, mas porque comestes dos pães e vos saciastes" (Jo 6,26). Na sequência, explicita abertamente o caminho da cruz e o que significa comer seu corpo e beber seu sangue. Isso as pessoas consideram duro demais e se colocam em debandada: "A partir daí, muitos dos seus discípulos voltaram atrás e não andavam mais com ele" (Jo 6,66). Ao que Jesus interpela os doze: "não quereis também vós partir?" (v. 67). Simão Pedro, respondeu: "Senhor, a quem iremos? Tens palavras de vida eterna e nós cremos e reconhecemos que tu és o Santo de Deus" (Jo 6,68-69). É a pergunta cortante sobre a disposição de seguimento de Jesus e sobre a consciência da necessidade de arcar com o peso da cruz. Por que seguimos a Jesus? As pessoas percebem sinais de amor, de renúncias, de radicalidade na opção dos cristãos em vista da justiça, da casa comum e no projeto do Reino de Deus? 
Retomando os evangelhos, outra realidade que se vislumbra na prática de Jesus é a relativização dos bens em vista da vida. Significa colocar os bens do mundo a serviço da vida. Cena chamativa, neste sentido, acontece quando os discípulos colhem espigas de trigo para saciar sua fome, em campos alheios, em dia de sábado, como nos relata São Marcos (Mc 2,23-28). Segundo os fariseus, é sábado e não é permitido, porque descumprem uma das leis mais sagradas dos judeus. Não importa, nesse caso, se está em jogo o problema da lei do sábado ou da colheita dos bens alheios. A resposta de Jesus é profética: "O sábado foi feito para o homem, e não o homem para o sábado" (v. 27) ${ }^{1}$. Em São Mateus, o questionamento aparece depois que Jesus cura um homem em dia de sábado. Na resposta, Jesus compara entre o valor de uma ovelha resgatada de um buraco e o do ser humano. O que se faz, se cair uma ovelha no buraco em dia de sábado? Não irão socorrê-la? Portanto, se vale para o animal, muito mais ao ser humano, fonte de dignidade absoluta ( $\mathrm{Mt}$ 12,11-12).

O teólogo Maria José Castillo, depois de passar em revista os textos eucarísticos do Novo Testamento, conclui com duas ideias interligadas. Uma, "a eucaristia é fato comunitário, isto é, não existe nenhum texto no qual a eucaristia aparece como gesto individual realizado por um indivíduo e para um indivíduo, mas se trata sempre de algo partilhado por um grupo". Outra, a Eucaristia é comida sempre partilhada. "Significa que não é 'coisa' santa e sagrada, mas uma ação que, logicamente, comporta determinado simbolismo"2.

Outra característica destacada por Castillo é o fato de Jesus instituir a Eucaristia em uma refeição (ceia de despedida). Fato

1 Cf. Ildo Bohn GASS, Jesus sobrepõe às leis o direito à vida. 28 de maio de 2018. Disponível em: https://cebi.org.br/reflexao-do-evangelho/jesus-sobrepoe-as-leiso-direito-a-vida/. acesso em 01 de agosto de 2020.

2 Cf. José María CASTILLO, Eucaristia. In: C. F. SAMANES; José TAMAYO ACOSTA (orgs.), Dicionário de conceitos fundamentais do cristianismo, p.252-253. Grifo do autor. 
que remete a uma prática de Jesus e de sua comunidade, o que considera algo expressivo. E, assim como se assinalou acima, Castillo também chama a atenção para os contextos polêmicos das refeições de Jesus. 1) Jesus e seus discípulos não se encaixam às normas rituais e religiosas, que todo judeu observante levava em consideração (Mc 7,2-5; Mt 12,21; Jo 18,28). 2) Compartilham à mesa pessoas desacreditadas, como pecadores e gente indesejável (Mc 2,16; Lc 15,2). 3) A comunidade de Jesus não jejuava conforme as prescrições exigidas pela lei (Mc 2,1718). 4) Os inimigos de Jesus também o acusavam de ser comilão e beberão (Mt 11,18-19). São elementos claros que revelam que Jesus e sua comunidade rompem com a teologia estabelecida por aquele sistema religioso. Porque: "O verdadeiro sentido teológico da comida partilhada, segundo o ensinamento evangélico, consiste em compartilhar a vida e se solidarizar com os pobres e desamparados deste mundo"3.

Ora, essas passagens dos Evangelhos visualizam a percepção da constância das refeições na vida de Jesus, bem como das dificuldades das autoridades, das classes abastadas e dos próprios discípulos de aceitarem a mesa como símbolo da comunhão, da fé, da justiça e do amor como doação total (Jo 13,1).

\section{Banquete de despedida: "Fazei isto em memória de mim"}

O fato de Jesus realizar uma ceia para se despedir na véspera de sua morte aparece, por um lado, sem surpresa na vida dos discípulos e, por outro, está em continuidade com o pilar fundamental de sua vida. Quer dizer, uma refeição estava totalmente em ordinário com a prática de Jesus, ou seja, despede-se da mesma forma como viveu. O antes, o durante e o depois estão em sintonia e comunhão profunda em Jesus de Nazaré. Jesus é aquele que passou pelo mundo fazendo o bem,

3 José María CASTILlO, Eucaristia. In: C. F. SAMANES; José TAMAYO ACOSTA (orgs.), Dicionário de conceitos fundamentais do cristianismo, p.253. 
como recorda São Pedro (At 10,38), se despede dos seus com uma refeição. É o testamento autorizado e missionário para que os discípulos não duvidem da necessidade de continuar fazendo isto em memória de Jesus.

Com esse pano de fundo, fica mais fácil entender o apóstolo Paulo, quando reclama da falta de fraternidade entre os membros da comunidade. Porque uns comem do que têm e antes dos outros, e os demais permanecem com fome. Desta forma, comem da própria condenação. "Eis porque todo aquele que comer do pão ou beber do cálice do Senhor indignamente será réu do Corpo e do Sangue do Senhor" (1Cor 11,29). E, às duras penas, Paulo consegue ajudar a comunidade a manter o critério fundamental: não se esquecer dos pobres (Gl 2,10) e a necessidade de superar todas as divisões, porque não há mais judeus ou gregos, escravos ou livres, homens ou mulheres (Gl 3,28). A fraternidade é a identidade cristã: "amai-vos uns aos outros" (Jo 15,17). O testamento repetido em todas as celebrações: "o amor de Cristo nos uniu".

Assim se entende, a relação intrínseca entre banquete eucarístico e amor ao próximo. Essa foi a grande missão das primeiras comunidades cristãs para manter-se na fidelidade à memória de Jesus e no desejo de se constituir em um só coração e uma só alma. Ainda, a luta para vencer a tentação da propriedade privada, colocando tudo em comum (At 2-4), projeto evangélico audacioso que peregrinou na história, não sem dificuldade, conforme o relato do casal, Ananias e Safira, que desviam o dinheiro de uma propriedade (At 5,1-11). Atitude designada como pecado contra o Espírito Santo.

É nessa matriz bíblica que está fundamentada a vida cristã, e fazer memória é atualizar esse ensinamento sempre pertinente na história do cristianismo. Então, ao dizer sim ao batismo, os cristãos estão assumindo esse compromisso de morrer para uma determinada forma de vida e mergulhar no estilo de Jesus. Um mergulho por inteiro na missão de ser uma nova criatura, um 
novo nascimento, como Jesus exigiu de Nicodemos (Jo 3,1-36). Nascer de novo é colocar-se a caminho dessa meta e deixar-se converter pelas águas do Cristo crucificado-ressuscitado, a fim de ser instrumento de Deus no mundo.

As diferentes refeições e a ceia de despedida, com a presença, inclusive, de Judas apontam para as tensões e os conflitos diante do seguimento. Judas expressa a decisão, o não compromisso com Jesus. Jesus e os discípulos suportam Judas durante todo o tempo da missão, esperando sua conversão. No entanto, Judas se mostra sempre mais fora da memória de Jesus para assumir a memória do mundo, das autoridades, das classes políticas. A noite do mundo, Nicodemos conseguiu superar, mas Judas não. A saída de Judas não é rejeição do grupo dos discípulos. Sua adesão decisiva ao grupo dos guardas, das autoridades e dos sumos sacerdotes do Templo fez de Judas um infiel ao projeto do Reino de Deus. Quem não faz aliança com o grupo de Jesus faz aliança com seus opositores. Quem não participa do banquete de Jesus, participa de outro banquete. Não há neutralidade: ou se escolhe a vida ou, a morte (Dt 30,15-20). Judas tem nas mãos a vida e a morte e escolhe a morte, rompendo a Aliança. Na verdade, é à mesa que Judas confirma não ter tido comunhão com Jesus e com seu grupo, durante $o$ ministério e durante os ensinamentos ${ }^{4}$.

Outrossim, a atitude de Judas expressa a total contradição de comungar do pão e não do projeto de Jesus. O banquete eucarístico desponta, portanto, como elemento de discernimento na vida dos cristãos. Alimento de Jesus, também, para os fracos, excluídos, rejeitados e não prêmio para os bons, como assegurou o Papa Francisco: "A Eucaristia não é um prêmio para os bons, mas remédio para os fracos”. E declara que o Reino de Deus é uma festa: "Por isto peçamos que dê de comer a todos nós. Dar de comer aquele alimento espiritual que

4 Cf. Isidoro MAZZAROLO, Lucas em João, p.91. 
nos fortifica, à mesa na Eucaristia, mas também dar de comer a todos, neste mundo onde o reino da fome é tão cruel" 5 .

Atualmente, presenciamos cristãos clamando: "Queremos Eucaristia..."; "Estou com saudade de comungar..."; "Tenho direito a Eucaristia ...”. O que esses gritos estão revelando? Uma experiência eucarística, como memorial da vida em abundância levado a cabo por Jesus até a cruz, ou a experiência de um alimento espiritual, sem implicância religiosa, social e política no mundo? Jesus, ao se despedir dos discípulos, garante a unidade d'Ele com o Pai: "Eu e o Pai somos Um" (Jo 10,30). Os cristãos, ao participarem do banquete eucarístico, se tornam outro Cristo? Quem vê os cristãos comungarem, entrarem na filha da Eucaristia todos os domingos, como imagina sua atuação moral, ética, social e política ... durante a semana?

A Eucaristia é o desejo trinitário de um mundo de fraternidade e de justiça. Segundo Gustavo Gutiérrez, a unidade profunda das diferentes significações que o termo koinonia tem no Novo Testamento poderia se resumir em três realidades. Em primeiro lugar, a partilha dos bens necessários à existência terrestre. "Não deixeis de fazer o bem e compartilhar os bens, por que esses são os sacrifícios que agradam a Deus" (Hb 13,16; At 2,$44 ; 4,32)$. É assim um gesto concreto de caridade fraterna. Por isso, Paulo utiliza esta palavra para se referir à coleta em favor dos cristãos de Jerusalém. "Esses glorificam a Deus pela generosidade de sua comunhão com eles e com todos" (2Cor 9,13; 2Cor 8,3-4; Rm 15,26-27). Em segundo lugar, a koinonia designa também a união dos fiéis com Cristo, por meio da Eucaristia: "O cálice da bênção que abençoamos, não é a comunhão com o sangue de Cristo? E o pão que partimos não é comunhão com o Corpo de Cristo?” (1Cor 10,16). Koinonia significa, finalmente, a união dos cristãos com o Pai: "Se

5 Disponível em: https://noticias.cancaonova.com/especiais/pontificado/francisco/ eucaristia-nao-e-premio-para-os-bons-e-remedio-para-os-fracos-diz-papa/. Acesso em 14 de maio de 2020. 
dizemos que estamos em comunhão com Ele e caminhamos nas trevas, mentimos e não procedemos conforme a verdade" ((1)o 1,3.6); com o Filho: "Pois fiel é Deus, por quem fomos chamados à comunhão com seu Filho" (1Cor 1,9; 1Jo 1,3); e com o Espírito: "A graça do Senhor Jesus Cristo, o amor de Deus e a comunhão do Espírito Santo esteja com todos vós" (2Cor 13,13; Fl 2,1) $)^{6}$.

A fraternidade humana, portanto, tem seu fundamento na plena comunhão com as Pessoas Trinitárias. O laço que une a realidade divina com a humana é recordado e anunciado eficazmente na Eucaristia. Significa que, sem um real compromisso contra os mecanismos de opressão e de alienação, e, portanto, a favor de uma sociedade igualitária e justa, a celebração eucarística é um ato vazio. Fazer memória de Cristo é mais que realizar um ato cultual; é aceitar viver sob a perigosa profecia da cruz e da esperança da ressurreição. É aceitar o sentido de uma vida que chegou até a morte, d'Aquele que passou pelo mundo fazendo o bem e foi reconhecido pelo centurião romano, como realmente Filho de Deus (Mc 15,39).

Um texto de São Mateus é claro a respeito da relação entre culto e fraternidade humana. "Portanto, se estiveres para trazer a tua oferta ao altar e ali te lembrares de que o teu irmão tem alguma coisa contra ti, deixa a tua oferta ali diante do altar e vai primeiro reconciliar-te com o teu irmão; e depois virás apresentar a tua oferta" (Mt 5,23-24). Não se trata do problema de uma consciência escrupulosa e sim de viver segundo as exigências do amor. Significa que ser causa de queda da fraternidade humana desqualifica para participar da celebração do Senhor. Porque a celebração com o Senhor é a mais pura manifestação do amor da família humana e cósmica. Por isso, o Evangelho de Mateus insiste na necessidade do perdão infinito

6 Cf. Gustavo GUTIÉRREZ, Teologia da libertação, p.325. 
(70 vezes 7), porque com as relações humanas quebradas não há verdadeiramente banquete eucarístico (Mt 18,21-22).

A comunidade cristã não pode oferecer de maneira autêntica o sacrifício de Cristo se antes não realizar de modo efetivo, o preceito do amor ao próximo. Desligar esse sacrifício do amor ao próximo é a razão das duras críticas dos profetas e do próprio Jesus. Ora, se o serviço ao próximo estivesse ausente, neste caso, a oração e toda a liturgia, como também o falar de Deus, não passariam de falsidade e hipocrisia. Assim entendia São Paulo, por isso, antes de relatar a instituição da Eucaristia, assinala a condição necessária para fazer parte do banquete. É o que critica na comunidade dos coríntios, quando de suas reuniões para celebrar a ceia do Senhor (1Cor 11,17-34; Tg 2,1-4) ${ }^{7}$.

Da mesma forma, o biblista Isidoro Mazzarolo realça que a Eucaristia é uma festa, uma reunião e uma refeição. Na sua etimologia é uma ação de graças. Ela não pode suportar a contradição, nem ser uma simples memória do passado, mas a historicização do compromisso, da aliança com outro e com o mundo na dinâmica de Cristo. A dimensão escatológica da Eucaristia como banquete perfeito não se separa jamais na mesa do mundo. É aqui na história de nossos dias, no tempo presente, na criação que geme e sofre em dores do parto $(\mathrm{Rm} 8,22)$ que a salvação acontece. É o compromisso na história que constrói a libertação. Ela exige uma comunhão com os pobres do mundo $\left(\right.$ Lc 6,20-23) ${ }^{8}$.

\section{Banquete da vida: "Tomai e comei"}

É na refeição que Jesus se despede antes de enfrentar o sacrifício do Calvário e da Cruz. Sua despedida não foi uma negação de sua vida, mas a entrega total dela para que os sinais do Reino de Deus possam estar presentes na realidade histórica.

7 Cf. Gustavo GUTIÉRREZ, Teologia da libertação, p.323.

8 Cf. Isidoro MAZZAROLO, Lucas em João, p.94. 
A sua ausência física não será sinal de distanciamento ou de abandono, pelo contrário, será sinal de proximidade e de aconchego. Alias, Ele permanece vivo entre nós nas espécies do pão e do vinho que, quando transubstanciados pela ação do Espírito Santo, se tornam seu próprio Corpo e Sangue. "A transformação do pão e do vinho no Corpo e Sangue do Senhor não é um fim em si mesma, mas tem por finalidade fazer a Igreja, isto é, transformá-la no corpo místico". Quer dizer, "o corpo sacramental está orientado à nossa transformação 'em um só corpo', o corpo eclesial”"10.

É no banquete da vida que, pela atuação do presbítero in persona Christi, acontece essa ação do Espírito Santo sobre os dons do pão e do vinho. Mais especificamente, é "em virtude da prece eucarística pronunciada sobre eles, que os elementos da ceia se transformam substancialmente, de forma que - como declara solenemente Justino - não são mais 'um pão comum, nem uma bebida comum', mas 'a carne e o sangue daquele Jesus que se encarnou"'11.

É fundamental perceber que a ação do Espírito Santo não se dá só sobre os dons do pão e do vinho, mas também, sobre os fiéis que participam da celebração Eucarística.

Enquanto a epiclese sobre as oblatas pede a Deus Pai que mande o Espírito Santo para que transforme o pão e o vinho no corpo e no sangue do Senhor Jesus, a epiclese sobre os comungantes pede, para quem se prepara para fazer a comunhão, a transformação em um só corpo. Os dois pedidos não são independentes, mas constituem, de fato, uma única e mesma súplica ${ }^{12}$.

Assim, ao dizer aos apóstolos tomai e comei, Jesus está lhes confiando o alimento salutar que os manterá fiéis na

9 Cesare GIRAUDO, Redescobrindo a Eucaristia, p.8.

10 Cesare GIRAUDO, Redescobrindo a Eucaristia, p.11.

11 Cesare GIRAUDO, Redescobrindo a Eucaristia, p.22.

12 Cesare GIRAUDO, Redescobrindo a Eucaristia, p.47. 
continuidade da sua missão de anunciar o Reino de Deus. Da mesma forma, continua a dizer aos que participam da ceia eucarística que a Eucaristia é o sinal por excelência daqueles que fazem o bem, nutridos do projeto vivido por Jesus, que tem a defesa da vida sempre em primeiro lugar. Portanto, tomai $e$ comei é comprometer-se em ser no mundo um discípulo fiel de Jesus, tendo os mesmos sentimentos de Cristo Jesus (Fl 2,5). Porque, pela Eucaristia, Ele habita em nosso ser para sermos no mundo um com Ele.

Jesus é Deus-por-nós, Deus-conosco, Deus-em-nós. Jesus é Deus dando-se completamente, vertendo-se por nós sem qualquer reserva. Jesus não se apega a suas próprias posses. Ele dá tudo que existe para dar. 'Comei, bebei, este é o meu corpo, este é meu sangue... este sou eu para vós! ${ }^{13}$.

É o gesto tão simples e cotidiano de reunir-se em torno da mesa para a refeição que Jesus transforma em baquete da vida. Ao tomar o pão e o vinho e dizer que esses serão sinais eternos de sua presença viva entre nós, Jesus torna célebre um ato comum, mas que revela a essência do existir. A Eucaristia é um gesto humano que se tornou divino pela ação de Jesus, mas que deseja humanizar ainda mais as relações entre as pessoas que, ao participar deste banquete, se comprometem a fortalecer a comunidade, a amizade, a paz, o amor, a justiça, a esperança. Enfim, o desejo de um mundo novo, em que realmente "Deus seja tudo em todos" (1Cor 15,28c).

É no ato de dar-se de Jesus que o pão e o vinho se transformam pela ação do Espírito Santo em Corpo e Sangue. Isso é Eucaristia. Assim se entende melhor que o sacrifício é parte integrante da ação de Jesus para a edificação do Reino de Deus e a salvação da humanidade. É nesse sentido que a participação na Eucaristia só se torna plena se a vida se tornar

13 Henri J. M. NOUWEN, Com o coração em chamas, p.54. 
Eucaristia: comunhão com Deus e comunhão com os irmãos.

Esta comunhão, pode-se dizer que está no mais íntimo desejo de Deus. No entanto, Deus respeita a liberdade e o tempo de cada ser humano. Ninguém é forçado! É verdade que Deus vai aos extremos do amor para tocar o coração humano.

Comunhão é o que Deus quer e o que nós queremos. É o clamor mais profundo de Deus e de nosso coração, porque fomos feitos com um coração que só pode ser satisfeito por quem o fez. Deus criou em nosso coração um desejo por comunhão que ninguém além de Deus pode e quer realizar. Deus sabe disso. Nós, raramente ${ }^{14}$.

A Eucaristia é a comunhão com Deus por excelência. Por ela se pertence ao Reino de Deus: "Quem comer deste pão viverá eternamente" (Jo 6,51b). Mas ela não é fim em si mesma, pois remete à missão de continuar a obra de Deus, a qual só será completa no fim dos tempos. A cada ação em defesa da vida se realiza mais comunhão com Deus e mais concorpóreos de Cristo nos tornamos. Revela-se, desta forma, que é Ele que está agindo no ser humano levando a pleno efeito a participação da humanidade no banquete da vida.

A presença real não nos foi dada só para que possamos adorar a Cristo sob as espécies eucarísticas; a comunhão não nos foi dada principalmente para que possamos encontrar e receber no coração o amigo Jesus, a quem fazemos, por alguns instantes, uma fervorosa e afetuosa companhia. O Senhor não instituiu a eucaristia em função de nossos olhos que a contemplam. Ele a instituiu em função de nossas bocas que se nutrem dela: instituiu-a para que a comêssemos ${ }^{15}$.

É em torno da mesa do altar que se estabelece comunhão com Deus e através da comensalidade do Corpo e do Sangue de Cristo, que Ele vai assumindo a vida de quem se deixa contagiar

14 Henri J. M. NOUWEN, Com o coração em chamas, p.57-58.

15 Cesare GIRAUDO, Redescobrindo a Eucaristia, p.49. 
por seu ensinamento. Então, no dizer de São Paulo, “já não sou eu que vivo, mas é Cristo que vive em mim” (Gl 2,20). De tal maneira que as ações dos comungantes devem estar em continuidade com as ações de Cristo, especialmente nos gestos de partilha e de defesa da vida. Essa é a verdadeira comunhão com Jesus: sermos como Ele, Bom Pastor, samaritano, misericordioso, humilde, justo, coerente, ético...

As primeiras comunidades cristãs (séculos I e II) tinham bem claro esse sentido do ser cristão e de viver a Eucaristia. Isso nos é confirmado pelo testemunho de Justino (martirizado em 165).

Depois, os que estão na abundância e querem dar, dão por livre escolha o que cada um deseja, e o que é recolhido, é depositado aos pés de quem preside; e ele mesmo socorre os órfãos e as viúvas e os que são negligenciados por enfermidade ou por outra causa e os que estão no cárcere e os que estão de passagem como forasteiros; numa palavra, faz-se protetor de todos os que estão em necessidade ${ }^{16}$.

É a partir da experiência vivida pelas primeiras comunidades cristãs que São Basílio chama a atenção sobre a relação entre a liturgia e o compromisso ético, a oração e a ação, já que são dois modos complementares e interdependentes de se viver a fé: "sem liturgia é difícil que se dê verdadeiro compromisso ético; sem compromisso ético é impossível que haja verdadeira liturgia”. A partir dessa compreensão, a Eucaristia, que tem em sua essência a transformação num só corpo, é vertical e horizontal ao mesmo tempo. "A dimensão vertical, nosso direcionamento e atenção a Deus, encontra sua verificação natural na dimensão horizontal, em nosso direcionamento e atenção àqueles de quem devemos fazer-nos próximos"17.

No dizer de Cesare Giraudo: "uma Eucaristia sem a vontade de assumir compromissos éticos - sobretudo com o próximo 16 JUSTINO, Apologia 67,6-7.

17 Cf. Cesare GIRAUDO, Redescobrindo a Eucaristia, p.57. 
é, para quem dela participa, uma eucaristia nula. Sem compromissos operosos, o culto se torna um passatempo cômodo, um culto vazio, uma aparência de culto" ${ }^{18}$, semelhante aos cultos criticados pelo profeta Isaías (Is 1,14) e pelo profeta Amós (Am 5,21-23).

Tomai e comei é permitir e contribuir para que a ação de Deus na história continue a partir de mulheres e homens comprometidos com o testemunho dos valores do Evangelho. A humanidade não pode ser espectadora da história! Deus conta conosco, por isso "Ele nos deu olhos para ver, ouvidos para ouvir, mãos para atuar. Nossos olhos devem ser os olhos com que Deus vê as necessidades, nossos ouvidos, os ouvidos com que Deus escuta os lamentos, nossas mãos, as mãos de que Deus se serve para vir em socorro"19. Assim, nossas eucaristias atingem sua plenitude porque conduzem os fiéis à ação diante da realidade, vivendo uma profunda experiência de pertencer ao Senhor.

Por isso, é preciso redescobrir a Eucaristia como fonte e ápice da vida cristã, no sentido de transformar os seguidores de Cristo em pessoas apaixonadas pelo projeto do Reino de Deus. Desta forma, o amém confessado publicamente ao entrar na fila da comunhão vence a perspectiva individualista, e empurra os cristãos a assumirem decididamente o estilo de vida de Jesus crucificado-ressuscitado.

\section{Conclusão}

A Eucaristia, como fonte e cume da vida cristã, foi acolhida maravilhosamente pelo Concílio Vaticano II (LG 11). Depois de séculos de história, que cristalizou o banquete de Jesus em uma refeição quase mágica e distante da realidade do povo, o Concílio resgatou a centralidade do memorial eucarístico de

18 Cf. Cesare GIRAUDO, Redescobrindo a Eucaristia, p.57.

19 Cesare GIRAUDO, Redescobrindo a Eucaristia, p.57-58. 
Cristo. O resgate da Eucaristia como banquete do amor de Cristo é, em consequência, o alimento missionário para os cristãos eucaristizar o mundo. Conforme o Papa Francisco:

Na Eucaristia vemos que, no apogeu do mistério da Encarnação, o Senhor quer chegar ao nosso íntimo através dum pedaço de matéria. (...) [Ela] une o céu e a terra, abraça e penetra toda a criação. Por isso, a Eucaristia pode ser fonte de luz e motivação para as nossas preocupações pelo meio ambiente, e leva-nos a ser guardiões da criação inteira. Assim, não fugimos do mundo, nem negamos a natureza, quando queremos encontrar-nos com Deus (QA 82).

Este alimento, no entanto, não produz apenas uma transformação da pessoa, mas, como sacramento da unidade, "Cristo nos uniu" - aprofunda as relações de fraternidade entre os cristãos e sua relação com o mundo. O empenho em participar dignamente deste sacramento se atualiza no relacionamento com as pessoas. No trabalho diário se continua o sacrifício do altar, o qual se prolonga, desse modo, na vida. Frequentemente, é mais difícil realizar o sacrifício de oferta no cotidiano, dos conflitos, diante das dificuldades, do que celebrálo dentro de uma Igreja.

A reflexão fez perceber a centralidade das refeições na prática de Jesus. Urge como desafio voltar às narrativas bíblicas para redescobrir sempre de novo o frescor da prática de Jesus na vida cristã. Caminho que faz compreender a Eucaristia dentro da dinâmica geradora de vida, porque traz imbuída a reconciliação, a fraternidade, a justiça e o desejo de vida plena. A pandemia parece ter possibilitado a redescoberta da oração familiar, seja em torno da mesa antes das refeições, seja à noite. Perspectiva que vem ao encontro dos desafios levantados e impulsionados pelas novas diretrizes da ação evangelizadora do Brasil.

A Eucaristia é alimento processual do caminhante que se deixou transformar pela Palavra de Deus. Basta recordar a narrativa dos discípulos de Emaús para perceber o processo de 
evangelização realizado por Jesus antes de celebrar a refeição (Lc 24,13-35). Caminhou em silêncio, fez perguntas, ouviu atentamente as decepções, dialogou, falou a partir das Escrituras, fez memória histórica... Não foi esse gastar tempo determinante para que os discípulos compreendessem o projeto de Jesus e o convidassem a ficar com eles? Nesse caso, a refeição não foi a porta de entrada, utilizada por Jesus para evangelizar, mas um momento especial preparado no caminho. Por isso, com razão dizem os bispos nas Diretrizes Gerais da Ação Evangelizadora da Igreja no Brasil: "a pedagogia do processo mais do que um recurso metodológico, é uma mística profundamente enraizada na espiritualidade cristã" ${ }^{20}$.

Essa consideração dos bispos vem validar a necessidade de gastar tempo nos processos de evangelização, como também, vem insistindo o Papa Francisco: "Dar prioridade ao tempo é ocupar-se mais com iniciar processos do que possuir espaços" (EG 223 grifos do Papa). Nos processos, "os evangelizadores contraem assim o 'cheiro das ovelhas', e estas escutam a sua voz. Em seguida, a comunidade evangelizadora dispõe-se a 'acompanhar"' (EG 24). Mais uma proposta pós-pandemia: fazer processo de evangelização, gastar tempo na missão.

Por isso, a Eucaristia, enquanto fonte e ápice da vida e missão da Igreja, deve traduzir-se em espiritualidade, em vida segundo o Espírito ( $\mathrm{Rm} \mathrm{8,4s;} \mathrm{Gl} \mathrm{5,16.25).} \mathrm{E} \mathrm{nesse} \mathrm{viver}$ segundo o Espírito se fundamenta a missão da Igreja no seio da história: "Uma Igreja autenticamente eucarística é uma Igreja missionária"21. É no seio desta experiência eclesial que se compreende que durante a pandemia, apesar das portas da Igreja/templos fechados houve muito envolvimento de vivência

20 CNBB: Diretrizes Gerais da Ação Evangelizadora da Igreja no Brasil 2019-2022, n.204.

21 BENTO XVI. Exortação apostólica pós-sinodal. Sacramentum Caritatis. Disponível em: http://www.vatican.va/content/benedict-xvi/pt/apost_exhortations/ documents/hf_ben-xvi_exh_20070222_sacramentum-caritatis.html. Acesso em 15 de maio de 2020, n.84. 
eucarística. Haja visto as diferentes iniciativas nos gestos de doação, solidariedade e distribuição de alimentos, roupas e outros auxílios para imigrantes, desempregados e necessitados em geral. São testemunhos que cimentam a relação intrínseca entre Eucaristia e vivência de amor ao próximo. Talvez esse seja um grande apelo pós-pandemia!

A Eucaristia, reforçamos, é a fonte e o ápice da vida da Igreja. Sem ela não formamos a Igreja de Cristo, mas também, se não formos pessoas eucaristizadas, ela não se plenifica em nós e corremos o risco de ser apenas alguém que comunga, mas não vive a comunhão. Outro desafio recorrente: eucaristizar o mundo!

\section{Referências Bibliográficas}

BENTO XVI, Papa. Exortação apostólica pós-sinodal. Sacramentum Caritatis. Disponível em: http://www.vatican.va/content/benedictxvi/pt/apost_exhortations/ documents/hf_ben-xvi_exh_20070222_sacramentum-caritatis.html. Acesso em 15 de maio de 2020.

BÍBLIA. Português. A Bíblia de Jerusalém. Nova edição revisada e ampliada São Paulo: Paulus, 2004.

CASTILLO, José María. Eucaristia. In: SAMANES, C. F; TAMAYO ACOSTA, José (orgs.). Dicionário de conceitos fundamentais do cristianismo. São Paulo: Paulus, 1999. p.252-259.

CNBB. Diretrizes Gerais da Ação Evangelizadora da Igreja no Brasil: 20192022. Brasília: Ed. CNBB, 2019.

FRANCISCO, Papa. Exortação Apostólica Evangelii Gaudium. A alegria do Evangelho. São Paulo: Paulinas, 2013. . Exortação Apostólica Pós-Sinodal - Querida Amazônia. Ao Povo de Deus e a todas as pessoas de boa vontade. São Paulo: Paulinas, 2020.

GASS, Ildo Bohn. Jesus sobrepõe às leis o direito à vida. 28 de maio de 2018. Disponível em: https://cebi.org.br/reflexao-do-evangelho/jesus-sobrepoeas-leis-o-direito-a-vida/. Acesso em e 01 de agosto de 2020.

GIRAUDO, Cesare. Redescobrindo a Eucaristia. São Paulo: Loyola, 2011, 5 aed. 
GUTIÉRREZ, Gustavo. Teologia da libertação: Perspectiva. São Paulo:

Loyola, 2000.

JUSTINO. Apologia 67,6-7.

MAZZAROLO, Isidoro. Lucas em João. Rio de Janeiro: Mazzarolo, 2017, $3^{\mathrm{a} e d .}$

NOUWEN, Henri J. M. Com o coração em chamas. Aparecida, SP: Editora Santuário, 2005, 4aed. 